\title{
PRODUCTION OF OUTER MEMBRANE VESICLES (OMV) IN BATCH CULTIVATION OF NEISSERIA MENINGITIDIS SEROGROUP B
}

\author{
Silvia Santos ${ }^{1}$, Júlia Baruque-Ramos ${ }^{2 *}$; Marta Massako Tanizakii'; Ivo Lebrun ${ }^{1}$; Rocilda Perazzini Furtado Schenkman ${ }^{1}$ \\ ${ }^{1}$ Instituto Butantan, Av. Dr. Vital Brazil, 1500, São Paulo, SP, Brazil; ${ }^{2}$ Universidade de São Paulo, Escola de Artes, Ciências e \\ Humanidades (EACH-USP), São Paulo- SP, Brazil
}

Submitted: December 13, 2005; Returned to authors for corrections: April 27, 2006; Approved: October 13, 2006

\begin{abstract}
Meningococcal disease is an important cause of death and morbidity throughout the world. Nearly 330,000 cases and 35,000 deaths occur yearly. Neisseria meningitidis, serogroup B strain N.44/89, is prevalent in Brazil. Its outer membrane vesicles (OMV) with iron regulated proteins (IRP) are released to the culture medium and are used as antigen for vaccine production. In order to have knowledge about the kinetic parameters, especially the final OMV concentration values, 20-h batch cultivations were carried out in Catlin medium with iron restriction. Process conditions comprised: $7 \mathrm{~L}$ bioreactor, $36^{\circ} \mathrm{C}, 0.5 \mathrm{~atm}$, overlay air flowrate of $1 \mathrm{~L} / \mathrm{min}$, agitation varying from $250 \mathrm{rpm}$ to $850 \mathrm{rpm}$ and dissolved oxygen control set at $10 \%$ of saturation condition. Biomass was determined by optical density at $540 \mathrm{~nm}$ and dry weight. Glycerol, lactate, $\mathrm{pH}$ and dissolved oxygen were measured from samples taken during cultivation. Outer membrane vesicle (OMV) concentration was determined by Lowry's method after ultracentrifugation. IRP presence was verified by SDS-PAGE. Highest biomass value, corresponding to the highest initial lactate concentration $(7.84 \mathrm{~g} / \mathrm{L})$ was achieved at the $9^{\text {th }}$ hour process time corresponding to $1.0 \mathrm{~g} / \mathrm{L}$ dry biomass and 2.3 optical density at $540 \mathrm{~nm}$. Lactate consumption was directly related to cell growth (yield factor: $0.24 \mathrm{~g}$ dry biomass / g lactate). Glycerol concentration in the medium did not change significantly during the process. OMV concentration reached the highest value of $80 \mathrm{mg} / \mathrm{L}$ at end cultivation time. The obtained results suggest that lactate is a main limiting growth factor and the maximum amount of antigen is obtained during stationary growth and cell death phases.
\end{abstract}

Key words: Neisseria meningitidis, outer membrane vesicles, culture medium, vaccine, submerged batch cultivation

\section{INTRODUCTION}

Meningococcal disease is an important cause of death and morbidity throughout the world. Nearly 330,000 cases and 35,000 deaths occur yearly (20). Besides disease and death, meningococcal meningitis is responsible for severe lesions, especially neurological, such as mental retardation, auditive deficiency, etc (16). In Brazil this disease has been a serious public health problem with high incidence and lethality in the last decades (7).
According to a common antimeningococcal vaccine project, against meningitis $\mathrm{B}$ and $\mathrm{C}$, a vaccine containing outer membrane vesicles (OMV) from $N$. meningitidis $\mathrm{B}$ expressing iron regulated proteins (IRP) from a strain with high incidence in Brazil (N 44/89) was suggested by Instituto Butantan, Instituto Adolpho Lutz and Fiocruz. The OMV must have the minimum amount of lipo-oligo-saccharide (LOS endotoxin), a constituent of these vesicles, in order to diminish the vaccine toxicity level, but maintaining vesicle integrity. In the Instituto Butantan the production process of $N$. meningitidis $\mathrm{C}(3,19)$;

*Corresponding Author. Mailing address: Universidade de São Paulo, Escola de Artes, Ciências e Humanidades - Av. Arlindo Bettio 1000. Cep 03828-000. São Paulo, SP, Brasil. Tel.: (11) 3091-1027. E-mail: ibaruque@usp.br 
the evaluation of the importance of a second serogroup B strain as vaccine component (9); the obtainment of vesicles with appropriate characteristics (with IRP expression and with low level of LOS); the conjugation process of $N$. meningitidis C polysaccharide with $N$. meningitidis B OMV $(12,13)$ were studied. In addition, it is worth mentioning that OMV also are employed as carriers of polysaccharides in conjugated vaccines against Haemophilus influenzae and in vaccines against pneumonia $(2,11)$.

Aiming at process optimization for OMV production, the $N$. meningitidis $\mathrm{B}$ growth kinetics and the yield evaluation of the amounts of produced OMV must be better studied. This means to identify the principal limitations, to determinate factors of OMV generation and to understand the relationship between cell growth and released OMV yield in the cultivation broth.

The objective of the present work is to study the growth, substrate consumption and released OMV production kinetics of Neisseria meningitidis, serogroup B strain N44/89, in bioreactor, aiming at the increase of OMV yield and the use of these data for further development and scaling up of the vaccine production process.

\section{MATERIALS AND METHODS}

\section{Process Conditions Preliminary cultivation runs}

Eight cultivation runs were carried out according to the factorial planning design $2^{3}(5)$ each one in shaken flasks of 300 $\mathrm{mL}$ capacity with $100 \mathrm{~mL}$ of Catlin medium without iron compounds, incubated at $300 \mathrm{rpm}$ and temperature controlled at $36 \pm 0.5^{\circ} \mathrm{C}$. The inoculum for each flask was prepared as that used in bioreactor cultivations (described below). The initial optical density at $540 \mathrm{~nm}$ was near 0.1 at the beginning of cultivations. The values adopted for the initial concentrations of L-glutamic acid, glycerol and lactate are listed in Table 1. The analysis of the effects was based on the optical density at 540 $\mathrm{nm}$ and released OMV values in each flask contents after 8 hours of cultivation.

\section{Cultivation runs in bioreactor}

The inoculum of Neisseria meningitidis Serogroup B - N 44/89 (Instituto Adolpho Lutz, São Paulo, Brazil) was prepared according to Gotschlich et al. (14). The content of one ampoule of the meningococcal strain, maintained at $-80^{\circ} \mathrm{C}$, in $1.0 \mathrm{~mL}$ Catlin

Table 1. Factorial planning design and analysis of results of preliminary experiments carried out in shaker.

(X1) Glycerol (g/L): $0(-) / 5.00(+)^{1}$

(X2) L-glutamic acid (g/L): $1.18(-) / 2.36(+)^{1}$

(X3) Lactate (g/L): $2.61(-) / 5.22(+)^{1}$

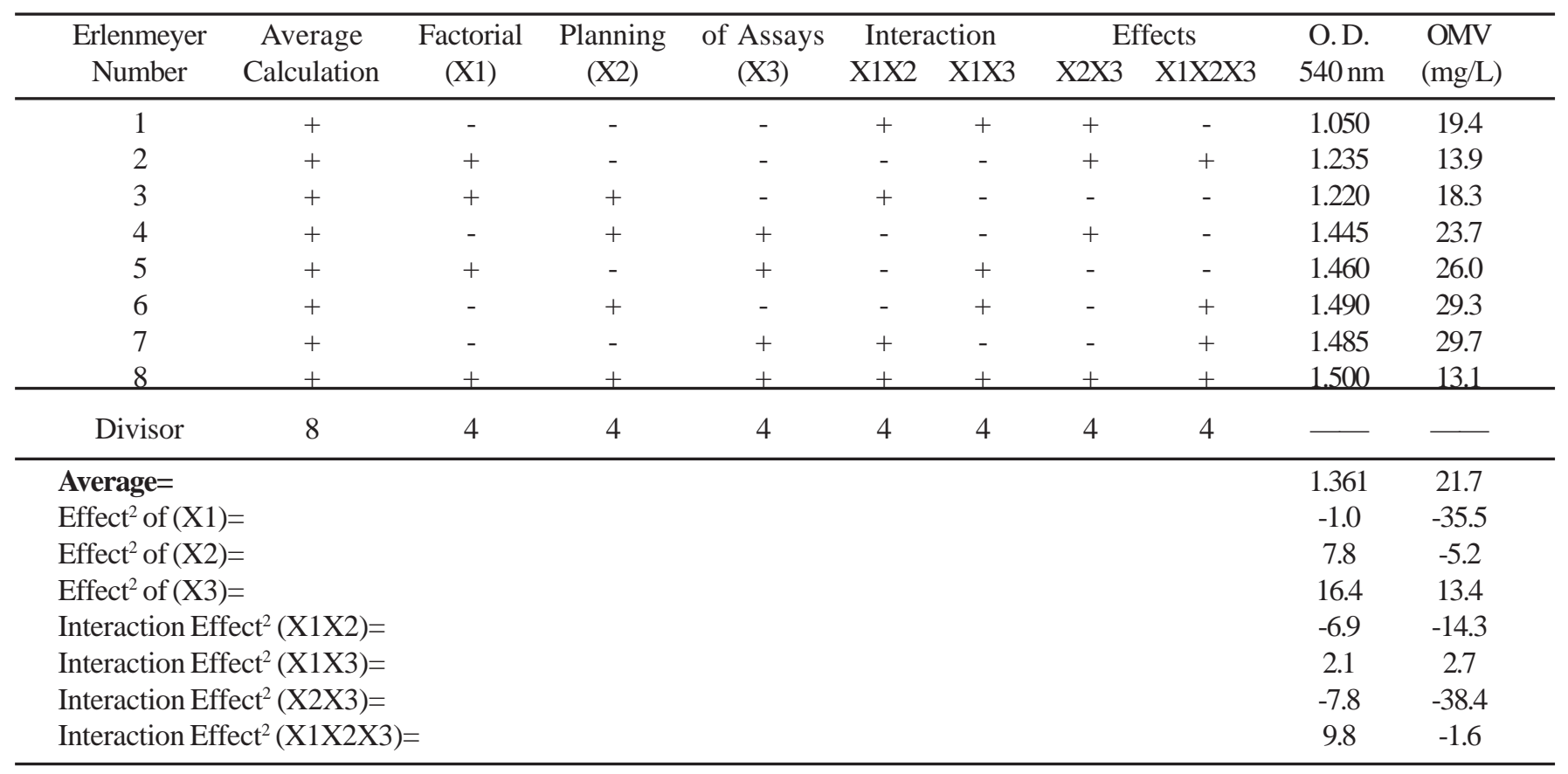

${ }^{1}$ Original concentrations in Catlin medium: 5.00, 1.18 and 7.500 g/L glycerol, L-glutamic acid and sodium lactate (50\% solution) respectively; ${ }^{2}$ Calculated in terms of percentage in relation to the respective average. 
medium without iron compounds (8) plus 30\% glycerol, was streaked out onto 5 Müller-Hinton agar slant tubes (18) and incubated at $36^{\circ} \mathrm{C}$ for $18-20 \mathrm{~h}$ in a candle jar $\left(5-10 \% \mathrm{CO}_{2}\right)$. The cells from each slant tube were resuspended in the liquid Catlin medium without iron compounds and then transferred to five $500 \mathrm{~mL}$ conical flasks, each containing $100 \mathrm{~mL}$ Catlin medium without iron compounds and incubated at $36^{\circ} \mathrm{C}$ for $3 \mathrm{~h}$ on a rotary shaker at $250 \mathrm{rpm}$. In order to verify possible contaminations, microscopic examinations were carried out using the Gram technique (4). The contents of conical flasks, corresponding to an initial optical density near 0.1 at $540 \mathrm{~nm}$, were used to inoculate a $7 \mathrm{~L}$ (total capacity) bioreactor (New Brunswick, model Bioflo 2000, New Jersey, NY) containing 4.2 L Catlin medium without iron compounds. The medium for the inoculum as well as for the bioreactor was sterilized by filtration through Millipore filters with $0.2 \mu \mathrm{m}$ mean pore diameter. Composition of Catlin medium without iron compounds ( $\mathrm{g}$ per liter) was: $5.850 \mathrm{NaCl} ; 0.401 \mathrm{NH}_{4} \mathrm{Cl} ; 0.186 \mathrm{KCl} ; 2.678$ $\mathrm{Na}_{2} \mathrm{HPO}_{4} .12 \mathrm{H}_{2} \mathrm{O} ; 0.170 \mathrm{KH}_{2} \mathrm{PO}_{4} ; 0.647$ sodium citrate. $2 \mathrm{H}_{2} \mathrm{O} ; 7.500$ sodium lactate $\left(50 \%\right.$ solution); $0.616 \mathrm{MgSO}_{4} .7 \mathrm{H}_{2} \mathrm{O} ; 0.037$ $\mathrm{CaCl}_{2} .2 \mathrm{H}_{2} \mathrm{O} ; 1.180$ L-glutamic acid; $0.021 \mathrm{~L}$-serine; $0.010 \mathrm{~L}-$ cysteine. $\mathrm{HCl} . \mathrm{H}_{2} \mathrm{O} ; 0.105 \mathrm{~L}$-arginine. $\mathrm{HCl} ; 0.150$ glicine; 0.001 $\mathrm{MnSO}_{4} \cdot \mathrm{H}_{2} \mathrm{O} ; 5.000$ glycerol. The $\mathrm{pH}$ was adjusted to 7.0 with a $5 \mathrm{~N} \mathrm{NaOH}$ solution. The bioreactor operating conditions were: temperature $=36.0^{\circ} \mathrm{C}$; air flow rate $=1 \mathrm{~L} / \min (0.22 \mathrm{vvm})$; upper aeration, $\mathrm{k}_{\mathrm{L}} \mathrm{a} \cong 5.3 \mathrm{~h}^{-1}$; agitation frequency $=$ between 250 and $850 \mathrm{rpm}$; dissolved oxygen controlled at $10 \%$. The vessel head pressure was maintained at $0.5 \mathrm{~atm}$. Two Rushton six blade disc turbines $(\phi=6.5 \mathrm{~cm})$ were used for mixing, one located at $5.0 \mathrm{~cm}$ from the vessel bottom and the other at $15.0 \mathrm{~cm}$ from the first turbine. The $\mathrm{pH}$ was measured by an on-line sterilizable electrode (Ingold model 465-90, Mettler-Toledo, Alphaville-Barueri, Brazil). Dissolved oxygen concentration was detected by an on-line polarographic electrode (Ingold model 531, Mettler-Toledo, Alphaville-Barueri, Brazil). The $100 \%$ point was calibrated one hour before the inoculation, under the same cultivation conditions.

\section{Analytical Methods}

Cell concentration was expressed as optical density at 540 $\mathrm{nm}$ and dry biomass weight per liter $(\mathrm{g} / \mathrm{L})$ after centrifugation of a known-volume sample at 3,220x $g$ during 30 minutes, followed by pellet drying at $60^{\circ} \mathrm{C}$ for $48 \mathrm{~h}$. Colony forming units (CFU) were determined by counting the colonies of a previously diluted sample grown in chocolate Müller-Hinton agar medium (10) at $37^{\circ} \mathrm{C}$ for 24 hours. For glycerol concentration measures, the used method (1) was based on glycerol oxidation by sodium periodate, where glycerol reacts with sodium periodate in acid solution generating aldehyde and formic acid. The formic acid was titrated with a $\mathrm{NaOH}$ solution $(0.125 \mathrm{~N})$ and the consumed volume corresponded to the glycerol concentration. Lactate concentrations were determined employing an automatic enzymatic analyzer (Yellow Spring, model YSI 2700 Select, Yellow Springs, Ohio, USA). OMV were separated from supernatant cultivation after ultracentrifugation (Beckman, L8-M Ultracentrifuge, Palo Alto, CA, USA) of $50 \mathrm{~mL}$ samples at 30,000 rpm during 3 hours and resuspended in $0.5 \mathrm{~mL}$ water. Protein concentration in OMV resupensions were estimated by Lowry's method (17) and compared to a bovine serum albumin standard. To verify IRP presence an electrophoresis method was employed (21). A standardized amount of OMV sample was resuspended in a SDS-PAGE sample buffer containing mercaptoethanol and urea, which was heated to $100^{\circ} \mathrm{C}$ for 2 minutes and applied to a $10 \%$ acrylamide/bisacrylamide gel. After the run the gel was stained with $0.1 \%$ Coomassie blue. The expression of IRP in the fractionated OMV extracts was estimated by the presence of 70-108 kDa bands (6).

\section{RESULTS AND DISCUSSION}

\section{Analysis of the effects of the factorial planning on the preliminary assays}

The calculated effects and their interactions are presented in Table 1. According to the results of the final optical density at $540 \mathrm{~nm}$ the main effect was caused by the increase of initial sodium lactate (carbon source) concentrations in the cultivation medium. The variation of glycerol concentrations, another potential carbon source for the bacteria, did not seem to cause any effect on final cell concentration values. Moreover, the determination of the initial and final glycerol concentrations showed that this compound was not consumed during the cultivations (data not shown). However, analyzing the assays according to OMV concentration results, despite lactate concentrations still able to promote a positive effect, the main effect was promoted by the variation of glycerol concentrations and their interactions with L-glutamic acid and sodium lactate. In this way, despite glycerol concentration increase in the cultivation medium did not seem to promote cell growth, it possibly could exert a protective effect on OMV generation. Lglutamic acid concentration variation did not promote any significant effect at the employed levels.

These preliminary conclusions, therefore, allowed for the planning of the assays carried out in bioreactor. In these experiments, the original glycerol and L-glutamic acid concentrations were maintained. In order to study the influence of sodium lactate on cell growth and OMV generation, two extreme concentration values were chosen: one of them reproducing the original concentration in Catlin medium (7.50 $\mathrm{g} / \mathrm{L}$ of a $50 \%$ sodium lactate solution corresponding to $2.61 \mathrm{~g} / \mathrm{L}$ lactate) and the other, three-fold higher, a condition of excess of this compound $(22.5 \mathrm{~g} / \mathrm{L}$ of a $50 \%$ sodium lactate solution corresponding to $7.84 \mathrm{~g} / \mathrm{L}$ lactate). In addition, these extreme limits were chosen to study the limitating or inhibiting influence of this substrate on cell growth and released OMV production. 
Analysis of results obtained in experiments carried out in bioreactor

Typical growth curves are shown in Figure 1a, lactate consumption and $\mathrm{pH}$ in Figure $1 \mathrm{~b}$ and OMV release in Figure 1c. Comparing these kinetics, the substrate limitation is evident
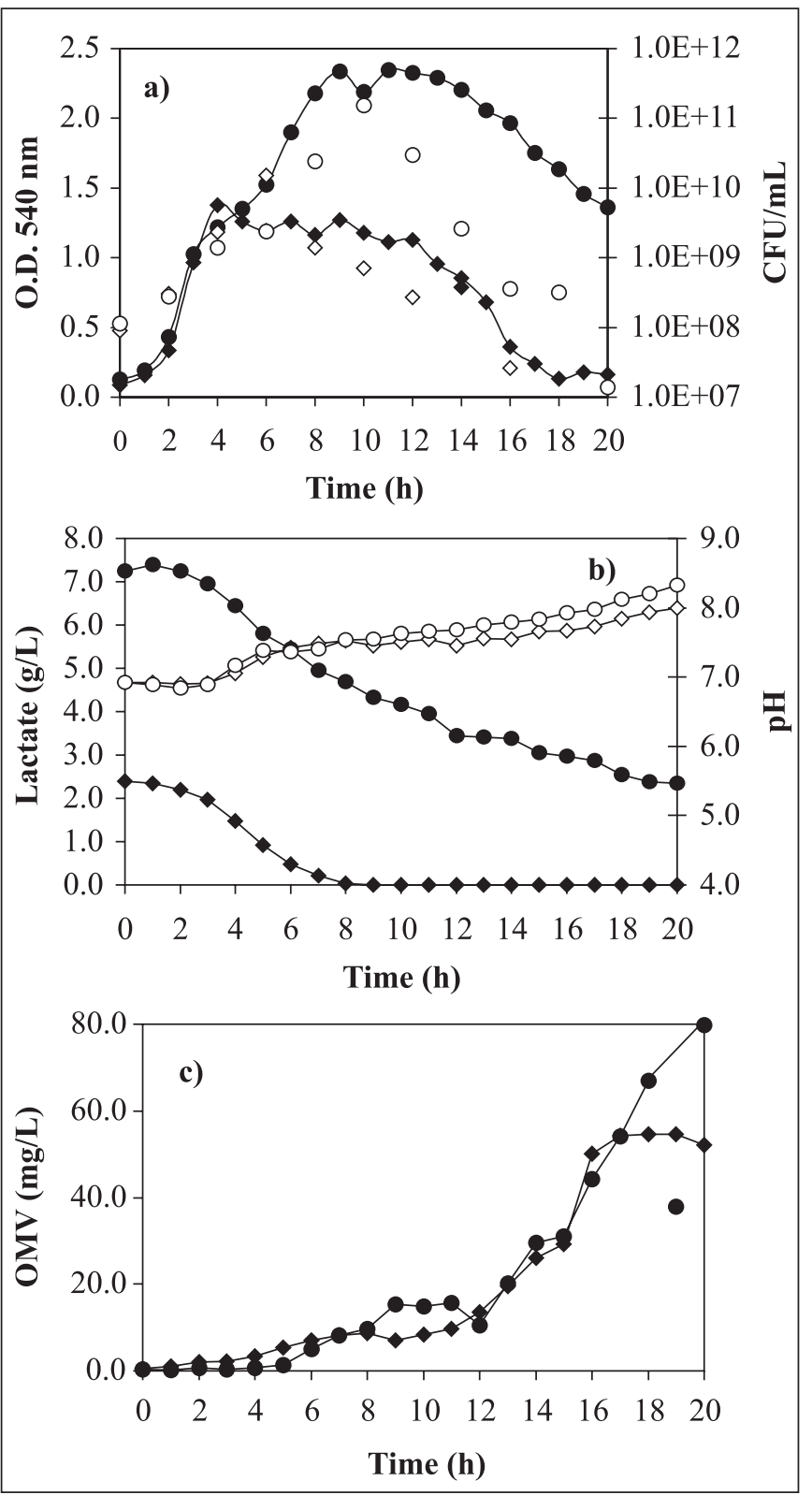

Figure 1. Growth, lactate consumption, $\mathrm{pH}$ and OMV formation kinetics - Assay with $2.61 \mathrm{~g} / \mathrm{L}$ initial lactate concentration: (a) O.D. $(\diamond)$ and CFU/mL $(\diamond)$; (b): Lactate $(\diamond)$ and $\mathrm{pH}(\diamond),(\mathrm{c})$ : OMV in supernatant $(\diamond)$; Assay with $7.84 \mathrm{~g} / \mathrm{L}$ initial lactate concentration: (a): O.D. ( ) and CFU/mL (O), (b): Lactate (O) and $\mathrm{pH}(\mathrm{O}),(\mathrm{c})$ : OMV in supernatant $(\mathbf{O})$. when $2.61 \mathrm{~g} / \mathrm{L}$ lactate was used in the medium (Figures 1a and 1b). In this experiment, the maximum cell concentration occurred at the $4^{\text {th }}$ hour whereas the lactate exhaustion occurred at the $8^{\text {th }}$ hour. Nevertheless OMV release to the cultivation medium began significantly from the $12^{\text {th }}$ hour on until the end of cultivation (Figure 1c) reaching the maximum value of near 60 mg per liter of cultivation. Cell population death occurred during this period and this fact was evidenced by the colony forming unit decrease (Figure 1a).

On the other hand, when $7.84 \mathrm{~g} / \mathrm{L}$ lactate was used in the medium, limitation by this substrate did not occur (Figures 1a and 1b). The optical density at $540 \mathrm{~nm}$ almost doubled in comparison to the other assay results, corresponding to $1.0 \mathrm{~g} /$ $\mathrm{L}$ dry biomass, but even in this way growth was limited by another substrate, which may be iron or another compound. Comparing both growth curves, they are almost the same until the $4^{\text {th }}$ cultivation hour. It can be concluded that the lactate excess at the level employed in the present work did not inhibit cell growth, even considering the excess of this substrate until the end of cultivation. Meanwhile as in the other assay, in this one OMV release to the cultivation medium also began significantly from the $12^{\text {th }}$ hour until the end of cultivation (Figure 1c) reaching the value of $80 \mathrm{mg} / \mathrm{L}$, i.e., $33 \%$ higher than the previous result.

It is worth mentioning that in both assays, there was IRP generation, marked by the presence of bands between 70 and $108 \mathrm{kDa}$ (Figure 2). Moreover, the determination of glycerol concentrations showed that this compound was not consumed during the cultivation periods (data not shown). In this way, the utility of glycerol in the cultivation medium still remains unclear. Also in both assays, $\mathrm{pH}$ increase, from 7.0 to values higher than 8.0, during cultivation time was observed (Figure 1b). According to these results, probably L-glutamic acid (main nitrogen source) was consumed, generating ammonia. In addition, this amino acid could be present in insufficient amounts for the cultivation requirements. These data lead to the supposition that the L-glutamic acid concentrations must be monitored and its initial concentration in the cultivation medium optimized in future studies according to the adopted process conditions.

Only one reference was found in the literature, which describes a suitable process of OMV production from $N$. meningitidis serogroup cultivations (11). According to this study, the original Catlin medium was modified to Catlin 6 medium, whose main carbon source is supplied by $10 \mathrm{~g} / \mathrm{L}$ of initial glucose concentration. However, despite those authors having described a final cell concentration of $5 \mathrm{~g} / \mathrm{L}$ dry biomass, they employed a medium with iron compounds and they did not elucidate the amount of obtained OMV and if its origin was from the supernatant or from the whole cultivation broth.

It was demonstrated that lactate is the main carbon source when original Catlin medium is employed for $N$. meningitidis 


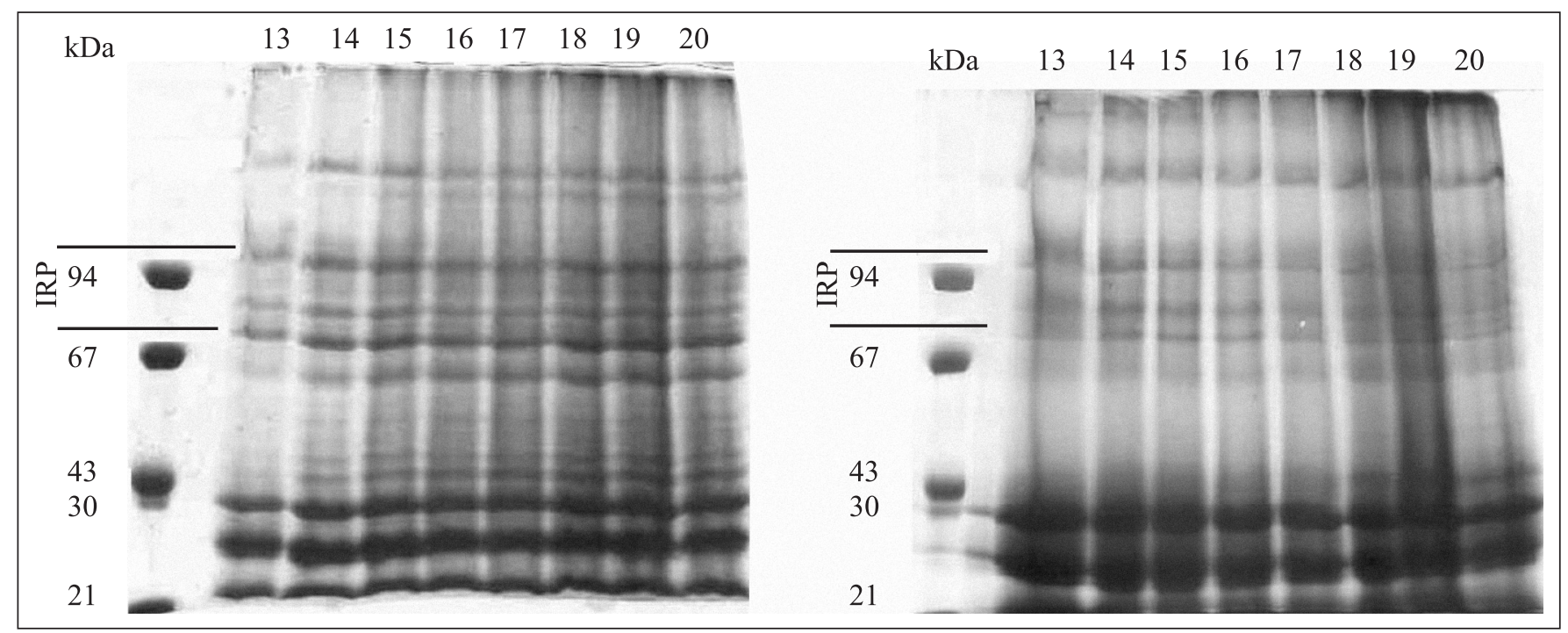

Figure 2. Expression of IRP (range from 70 to $108 \mathrm{kDa}$ indicated by arrows) in the fractionated OMV extracts. First line from left side indicates the molecular weight standards. Lines 13 to 20 correspond to the fractionated OMV extract at the respective cultivation hour. (a) Assay with $2.61 \mathrm{~g} / \mathrm{L}$ initial lactate concentration. (b) Assay with $7.84 \mathrm{~g} / \mathrm{L}$ initial lactate concentration.

serogroup B cultivation. According to the present study, considering an estimated relationship of 0.5 between the values of dry biomass and optical density at $540 \mathrm{~nm}$, the dry biomass/ lactate yield factor $\left(\mathrm{Y}_{\mathrm{X} / \mathrm{s}}\right)$ is near $0.24 \mathrm{~g} / \mathrm{g}$. The degradation of lactate by $N$. meningitidis $\mathrm{B}$ is described together with its genome and its functions (23). According to this study, the lactate degradation is accomplished by way of an intact tricarboxylic acid cycle (TCA), as well as pentose-phosphate and Entner-Doudoroff pathways. Probably the lactatedehydrogenase key enzymes can develop the two-way function of lactate generation (glycolysis) or lactate absorption (gluconeogenesis) in these pathways $(15,22)$.

In conclusion, the supplemental addition of three-fold more initial lactate concentration in Catlin medium in relation to the original initial concentration leads to an increase of $33 \%$ final OMV concentration (near $80 \mathrm{mg} / \mathrm{L}$ ) with confirmation of IRP presence. The OMV release, from cell surface to the cultivation medium, seems to be more intense during stationary growth and cell population death phases. The utility of glycerol in the culture medium still remains unclear, since it has been not consumed in cultivations. However, despite the positive preliminary results, the initial concentration of carbon sources (lactate and glycerol) as well as nitrogen source concentration must be optimized in future studies according to the adopted process conditions.

\section{ACKNOWLEDGMENTS}

Financial support from Fundação Butantan is gratefully acknowledged. We would like to thank CNPq for the research fellowship. The authors would also like to thank Mr. Lourivaldo Inácio de Souza, Mr. Máximo de Moraes, Mr. Hélio Fernandes Chagas, Mrs. Inês do Amaral Maurelli, Mrs. Salete Vargas and Mrs. Fátima Aparecida Mendonça de Oliveira for their technical support.

\section{RESUMO}

\section{Produção de Vesículas da Membrana Externa (OMV) em Cultivo Batelada de Neisseria meningitidis Sorogrupo B}

A doença meningocócica é uma causa importante de morte a nível mundial. Aproximadamente 330.000 casos e 35.000 mortes ocorrem anualmente. A cepa N.44/89 do sorogrupo B de Neisseria meningitidis é prevalente no Brasil. Suas vesículas de membrana externa (OMV - "outer membrane vesicles"), com proteínas reguladoras de ferro (IRP - "iron regulated proteins") liberadas no meio de cultura, são empregadas como antígeno para a produção da vacina. A fim ter o conhecimento sobre os parâmetros cinéticos, especialmente os valores finais da concentração de OMV, cultivos batelada de $20 \mathrm{hs}$ foram realizados no meio de Catlin com limitação do ferro. As condições de processo compreenderam: biorreator de 7 litros, $36^{\circ} \mathrm{C}, 0,5$ atm, vazão de ar de $1 \mathrm{~L} / \mathrm{min}$, agitação variando entre 250 a 850 rpm, controle do oxigênio dissolvido em $10 \%$ da condição de saturação. A biomassa foi determinada pela densidade ótica em $540 \mathrm{~nm}$ e peso seco. Glicerol, lactato, $\mathrm{pH}$ e oxigênio dissolvido foram medidos das amostras retiradas durante o cultivo. A concentração de OMV foi determinada pelo método de Lowry 
após ultracentrifugação. A presença de IRP foi verificada por SDS-PAGE. O valor mais elevado de biomassa, correspondendo à concentração inicial mais elevada de lactato $(7,84 \mathrm{~g} / \mathrm{L})$ foi obtido no tempo de processo de 9 horas, o qual corresponde a biomassa seca de 1,0 g/L e a densidade ótica de 2,3 em $540 \mathrm{~nm}$. O consumo de lactato. foi relacionado diretamente ao crescimento celular (fator de conversão de 0,24 biomassa por lactato g/g). A concentração do glicerol no meio não se alterou significativamente ao longo do processo. A concentração de OMV alcançou o valor mais elevado de $80 \mathrm{mg} / \mathrm{L}$ no tempo final de cultivo. Os resultados obtidos sugerem que o lactato é o principal fator limitante do crescimento e o máximo do antígeno é obtido durante a fase estacionária de crescimento e de morte celular.

Palavras-chave: Neisseria meningitidis, vesículas de membrana externa, meio de cultura, vacina, cultivo submerso descontínuo

\section{REFERENCES}

1. A.O.C.S. Method Ea 6-51. In: Official Methods and Recommended Practices of the American Oil Chemistry Society, AOCS, Illinois, 1987, p.6-51.

2. Ahonkhai et al., Clinical experience with PedvaxHIB, a conjugate vaccine of Haemophilus influenzae type b polysaccharide-Neisseria meningitidis outer membrane protein. Vaccine, 9(S): 38-43, 1991.

3. Baruque-Ramos, J.; Hiss, H.; Arauz, L.J.; Mota, R.L.; Ricci-Silva, M.E.; Paz, M.F.; Tanizaki, M.M.; Raw, I. Polysaccharide production of Neisseria meningitidis (Serogroup C) in batch and fed-batch cultivations. Biochemical Engineering Journal, 23: 231-240, 2005.

4. Bier O. Microbiologia e Imunologia. $24^{\text {th }}$ ed. Ed. Melhoramentos, São Paulo, 1985,1234p.

5. Box, G.E.P.; Hunter, W.G.; Hunter J.S. Statistics for Experimenters. John Wiley \& Sons, New York, 1978, 653p.

6. Brandileone, M.C.C.; Zanella, R.C.; Vieira, V.S.D.; Sacchi, C.T.; Milagres, L.G.; Frasch, C.E. Induction of iron regulated proteins during normal growth of Neisseria meningitidis in a chemical defined medium. Rev. Inst. Med. Trop., 36(4): 301-310, 1994.

7. Brazilian Epidemiological Vigilance Center, 2004. Prevenção da doença meningocócica e estratégia de controle. www.cve.saude.sp.gov.br actualized in april/2004, consulted in may/2005.

8. Catlin W. Nutritional profiles of Neisseria gonorrhoeae, Neisseria meningitidis, and Neisseria lactamica in chemically defined media and the use of growth requirement for gonococcal typing. The Journal of Infectious Disease, 128(2): 178-194, 1973.
9. Corrêa, A.P. Estudo de formulação das vacina anti-meningocócica polissacarídeo $C$, conjugada a vesícula de membrana externa $B$ de Neisseria meningitidis. São Paulo, 2002, 47p. (MsC Thesis, Interunidades em Biotecnologia USP/I. Butantan/ IPT).

10. Difco manual. Dehydrated Culture Media and Reagents for Microbiology, $10^{\text {th }}$ ed., Difco Laboratories, Detroit, 1985, p.595.

11. Fu, J. et al. Recent advances in the large scale fermentation of Neisseria meningitidis group B for the production of an outer membrane protein complex. Bio/Technology, 13: 170-174, 1995.

12. Fukasawa, L.O.; Gorla, M.C.; Lemos, A.P.S.; Schenkman, R.P.F.; Brandileone, M.C.C.; Fox, J.W.; Raw, I.; Frasch, C.E.; Tanizaki, M.M. Immune response to native NadA from Neisseria meningitidis and its expression in clinical isolates in Brazil. Journal of Medical Microbiology, 52: 121-125, 2003.

13. Fukasawa, L.O.; Gorla, M.C.; Schenkman, R.P.F.; Garcia, L.R.; Carneiro, S.M.; Raw, I.; Tanizaki, M.M. Neisseria meningitidis serogroup C polysaccharide and serogroup B outer membrane vesicle conjugate as a bivalent meningococcus vaccine candidate. Vaccine, 17: 2951-2958, 1999.

14. Gotschlich, E.C.; Liu, T.Y.; Artenstein, M.D. Human immunity to the meningococcus - III. preparation and immunochemical properties of the series A, series B and series C meningococcal polysaccharides. J. Exp. Med., 129: 1349-1365, 1969.

15. Leighton, M.P.; Kelly, D.J.; Williamson, M.P.; Shaw, J.G. An NMR and enzyme study of the carbon metabolism of Neisseria meningitidis. Microbiology, 147: 1473-1482, 2001.

16. Lepow, M.L.; Perkins, B.A.; Hughes, P.A.; Poolman, J.T. Meningococcal vaccine. In: Plotkin AS, Orenstein WA eds. Vaccine, $3^{\text {rd }}$ Ed. Philadelphia, Saunders, 1999, p.711-727.

17. Lowry, O.H.; Rosebrough, N.J.; Farr, A.L.; Randall, R.H. Protein measurement with the Folin phenol reagent. J. Biochem. Chem., 193: $265-275,1951$.

18. Müller, H.; Hinton, J.A. A protein-free medium for primary isolation of the gonococcus and meningococcus. Proc. Soc. Exp. Biol. Med., 48: 330, 1941.

19. Paz, M.F.; Baruque-Ramos, J.; Hiss, H.; Vicentin, M.A.; Leal, M.B.B.; Raw, I. Polysaccharide production in batch process of Neisseria meningitidis serogroup $\mathrm{C}$ comparing Frantz, modified Frantz and Catlin 6 cultivation media. Braz. J. Microbiol., 34(1): 27-32, 2003.

20. Romero, J.D.; Outschoorn, I.M. Current status of meningococcal group B vaccine candidates: capsular or noncapsular? Clinical Microbiology Reviews, 7: 559-575, 1994.

21. Sambrook J.; Fritsch E.F.; Maniats T. Molecular cloning: a laboratory manual. $2^{\text {nd }}$ ed. Cold Spring Harbor Lab Press, New York, 1989, v. A.3, p.6.1-6.60

22. Smith, H.; Yates, E.A.; Cole, J.A.; Parsons, N.J. Lactate stimulation of gonococcal metabolism in media containing glucose: mechanism, impact on pathogenecity, and wider implications for other pathogens. Infection and Immunity, 69(11): 6565-6572, 2001.

23. Tettelin, N.J. et al. Complete genome sequence of Neisseria meningitidis serogroup B strain MC58. Science, 287: 1809-1815, 2000. 